\title{
Adverse Effects of some of the Most Widely used Metal Nanoparticles on the Reproductive System
}

\author{
Shahla Abdollahii ${ }^{1}$, Faezeh Jadidi ${ }^{2}$, Marjan Safari ${ }^{1}$, Amir Mohammad Akbari Javar ${ }^{3}$, Nasrin

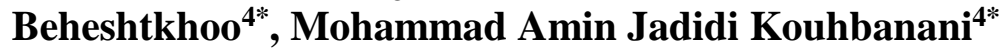 \\ ${ }^{1}$ Department of Medical Nanotechnology, School of Advanced Medical Sciences and Technologies, Shahroud University of Medical Sciences, \\ Shahroud, Iran \\ ${ }^{2}$ Student Resesrch committee, Zarand school of nursing, Kerman university of medical sciences, kerman,Iran \\ ${ }^{3}$ Department of Mathematics, faculty of Mathematics, Farhangian University, Kerman, Iran \\ ${ }^{4}$ Department of Medical Nanotechnology, School of Advanced Technologies in Medicine, Tehran University of Medical Sciences, Tehran, Iran
}

Received: 22/03/2020

Accepted: 15/07/2020

Published: 20/09/2020

\begin{abstract}
Nanotechnology, which allows the manipulation of molecular dimensions, is used in many aspects of human life, from industrial to medical and therapeutic aspects. Features of nanoparticles and their unique capabilities have attracted a lot of attention. Among nanotechnology structures, metal nanoparticles have been widely used in many aspects of industry and medicine. The unique properties of these nanoparticles make possible to produce and expand them on a large scale, thus making the possibility of exposure to these nanoparticles more likely. Nanotechnology and nanoparticles like a double-edged sword despite its many benefits, it also has a number of disadvantages. One of the most important of these disadvantages is their toxicity. This toxicity may have adverse effects on the environment and humans. One of the most important adverse effects of nanoparticles is adverse effects on the reproductive system. In this paper, the adverse effects of some of the most widely used metal nanoparticles on the reproductive system are described. These adverse effects can be on: sexual behaviors, sexual organs, sperm count, sperm motility, sperm shape, sperm maturity, ovarian and follicle maturation, their fertility rate and also the level of sex hormones in men and women. The adverse effects of these nanoparticles and their toxicity on a variety of tissues and organs lead us to use safer nanoparticles.
\end{abstract}

Keywords: Nanotechnology, Metal nanoparticles, Toxicity, Reproductive system

\section{Introduction}

Nanotechnology is defined as the use and manipulation of devices, materials, and systems in nanometer scale, 100 nanometer scale, where the resulting material has new physical and chemical properties that are not seen in its Balk counterparts. Some scientists believe that Nanotechnology is one of the key technologies in the 21 st century. This technology has revolutionized the field of medicine،information technology and materials. In the past 30 years, nanotechnology has become one of the areas where explosive growth has taken place in many dimensions (1-5). Many nanostructures include:fullerenes, nanoparticles, nanopowders, nanotubes, nanowires, nanorods, nano-fibers, quantum dots, dendrimers, nanoclusters, nanocrystals, and nanocomposites are produced on a large scale and are used in many aspects of human life (6). Nanotechnology potential applications in: cancer treatment (7), diagnostics (8), imaging (9), cosmetics(10), anti-aging(11), pollutiosensing $(12,13)$, hyperthermia (14), textile (15), catalysis (16-19), water and wastewater treatment (20), food industry (21), agriculture fertilizers (22), agriculture (23), drug delivery (24), biosensors and biotechnology (25) and many more have been proven so far. In many of its applications, including pharmacology, this technology has become a challenging innovation (26).

Metal nanoparticles have received a lot of attention due to their electronic and chemical properties, and many scientists are willing to use them in the development of new generation nanodevices (27). Metal nanoparticles have been widely used in targeted drug delivery, cancer treatment, gene therapy and DNA analysis, antibacterial agents $(28,29)$, biosensors, enhancing reaction rates, separation science, and magnetic resonance imaging (MRI) (30). Some metal nanoparticles, such as gold and silver nanoparticles, due to their unique and tunable optical properties on account of their surface plasmon resonance (SPR), are widely used in molecular-specific imaging and sensing, photo-diagnostics, and selective photothermal therapy (31). Therefore, although nanotechnology has played a very important role in development and progress in many different aspects: from cell phones to medicines, but also the negative dimensions of this modern technology and its toxic effects must be considered. Due to the widespread use of these nanostructures in various aspects of human life, human exposure to these nanostructures and nanotechnology is inevitable. It is the duty of these nanomaterials to enter and affect the various organs and tissues of the human body in various ways. These nanoparticles may have toxic effects that deformation and inhibition of cell growth.And thus cause various diseases in humans and animal $(6,32)$. There is a wealth of evidence to support the toxicity of some nanostructures, for example:Titanium oxide nanoparticles, which are widely used in cosmetics and skin care products, reactive oxygen, they create species and cause damage to DNA carbon nanotubes may cause lipide eroxidation, oxidative stress, mitochondrialdys function, and

*Corresponding authors: (a) Nasrin Beheshtkhoo, Department of Medical Nanotechnology, School of Advanced Technologies in Medicine, Tehran University of Medical Sciences, Tehran, Iran. E-mail: beheshtkhoo.nano@gmail.com. (b) Mohammad Amin Jadidi Kouhbanani, Department of Medical Nanotechnology, School of Advanced Technologies in Medicine, Tehran University of Medical Sciences, Tehran, Iran. E-mail: aminjadidi1993@gmail.com. 
changes in cell morphology upon in vitro incubation with keratinocytes and bronchial epithelial cells and thus be dangerous. Silver nanoparticles have been shown to be dosedependent toxicity and may cause oxidative stress in alveolar macrophages. Quantum dots and fullerenes cause inflammatory reactions and may also cause reactive oxygen species (33-40).

A large number of nanostructures by passing through biological barriers, they can have destructive and toxic effects on many human organs such as have the brain, liver, and kidney. Another important system that is affected by the toxic effects of nanoparticles is reproductive systems. There are many evidences that some nanoparticles can pass from the reproductive barrier systems such as the blood-testis barrier, placental barrier, and epithelial barrier, and then accumulate in the testis, epididymis, ovary, and uterus and eventually cause damage to these organs. The accumulation of nanoparticles in the reproductive system can have adverse effects on sperm and oocytes. These adverse effects include: adverse effects on quantity, quality, motility and sperm morphology, adverse effects on oocytes, detrimental effects on the development of primary and secondary follicles, negative effects on the number of mature oocytes and their reduction, detrimental effects on levels of secreted hormones and changes in sexual behavior. Although the exact mechanism of toxicity of nanoparticles on reproductive organs has not yet been completely elucidated, it is possible that some mechanisms, such as oxidative stress, apoptosis, inflammation, and genotoxicity play a role in the toxicity of nanoparticles and their destructive effects on the reproductive system (41-55)

\section{The reproductive system}

\subsection{The female reproductive system}

The female reproductive system has internal and external parts. External sections include labia majora, labia minora, Bartholin's glands, and clitoris. The internal parts also include the vagina, uterus, ovaries and fallopian tubes. The most important functions of the female reproductive system are: oocytes production, which can eventually act as an egg cell and play a role in the reproductive process, participation in the fertilization process, participation in the implantation process, participation in the menstrual cycle And It also produces some female sex hormones to maintain the reproductive cycle (56$58)$.

\subsection{The male reproductive system}

The male reproductive system also has internal and external parts. External genitalia include: the penis, scrotum, and testicles and the internal genitalia include: epididymis,vas deferens, ejaculatoryducts, urethra, seminal vesicles, and prostateGland, bulbourethral glands. The most important functions of the male reproductive system are: sperm production, sperm maintenance and protection. In this device, some sex hormones are also produced and secreted to maintain the reproductive system (59-62).

\section{Factors affecting on the toxicity of nanoparticles}

Size, shape, chemical composition, surface charge, solubility, the type of nanoparticle entry path into the body, the exposure time of nanoparticles. surface chemistry (PEGylation, ligand conjugation), bio distribution, penetration rate, bioavailability and Individual characteristics (age, sex) (63, 64).

\section{The main ways in which nanoparticles enter the reproductive system}

Dermal exposure, pulmonary exposure, and gastrointestinal exposure are the major pathways for nanoparticles to enter the reproductive system.

Dermal: Some nanoparticles used in cosmetics, such as nanotitanium dioxide, can enter the body through skin absorption. Various evidence suggests that the skin absorption rate of nanoparticles is very low. In this way, nanoparticles can be absorbed through the skin without causing significant toxicity (65-70).

Gastrointestinal: This route is one of the main entry and absorption pathways for nanoparticles. Most of the nanoparticles that used in food and the drugs that are taken orally enter the body through this pathway. The nanoparticles mainly enter the bloodstream and secondary organs after entering the gastrointestinal tract. The rate of absorption of different nanoparticles varies. Different nanoparticles have a longer duration in the large intestine and a shorter duration in the stomach. After entering and absorbing, nanoparticles are distributed through this pathway to various organs, including the liver, spleen, and mesenteric lymph nodes (71-74) .

Lung: Some nanostructures, such as cerium oxide, enter the body mainly through inhalation and remain in the lungs. Some other nanoparticles enter through inhalation and then enter the central nervous system through olfactory neurons $(75,76)$. There are many evidences that nanoparticles are absorbed into the bloodstream after entering each of these pathways and eventually enter organs such as the liver, spleen, kidney, brain, ovaries and testes (76).

\section{Some of the most widely used metal nanoparticles and their effect on the reproductive system \\ 5.1 Titanium dioxide nanoparticles $\left(\mathrm{TiO}_{2} \mathrm{NPs}\right)$}

$\mathrm{TiO}_{2}$ NPs are widely used in medical, diagnostic and cosmetic fields. The increasing use of these nanoparticles is highly toxic to humans. Some evidence suggests that TiO2 NPs lead to damage to follicles. These nanoparticles reduce follicular survival and prevent the development and maturation of oocyte. TiO2 NPs also have adverse effects on sperm. These nanoparticles have an adverse effect on sperm motility. These nanoparticles reduce the number of normal sperm but increases the number of abnormal sperm. Some other evidence suggests that these nanoparticles induce apoptosis in germ cells in the testicular mouse (77-81). The table 1 shows some of the effects of titanium dioxide nanoparticles on the reproductive system. 


\begin{tabular}{|c|c|c|}
\hline Orally & Body weight changes, relative changes in testicular weight and genitals. & $(82)$ \\
\hline- & $\begin{array}{l}\text { Some studies have shown that } \mathrm{TiO} 2 \mathrm{NPs} \text { can be found in cytoplasm and nuclei of ovarian cells } \\
\text { accumulate. Nanoparticles accumulated in the cell can induce apoptosis. In addition, the } \\
\text { mitochondria and nuclei of ovarian cells were disrupted. Mitochondrial swelling and rupture, } \\
\text { nuclear chromatin condensation,and irregularity of the nuclear membrane was also observed. }\end{array}$ & $(83-87)$ \\
\hline Intragastric & $\begin{array}{l}\text { Spermatogenesis suppressionThrough alterationsof testicular enzymes and oxidative stress in } \\
\text { the testes. }\end{array}$ & $(88)$ \\
\hline IP & $\begin{array}{l}\text { Changes in estrogen and progesterone levels, changes in ovarian tissue, loss of Graafian } \\
\text { follicles, destruction of follicles wall, reducing the thickness of Granulosa and Thec layers and } \\
\text { decreased corpus luteum. }\end{array}$ & $(89)$ \\
\hline Intragastric & $\begin{array}{l}\text { The direct effect of } \mathrm{TiO}_{2} \mathrm{NPs} \text { on ovarian function and consequently ovarian damage, as well } \\
\text { as these nano particles can cause an imbalance of mineral element distribution and sex } \\
\text { hormones, decrease fertility or the pregnancy rate and oxidative stress in mice. }\end{array}$ & $(5)$ \\
\hline Orally & $\begin{array}{l}\text { This study suggests that oral administration of } \mathrm{TiO}_{2} \mathrm{NP} \text { may alter ovarian tissue. These } \\
\text { changes include:Destruction of follicles, reduction of their number, disruption of follicle } \\
\text { growth, possibility of ovarian cyst formation, decrease in pregnancy rate, decrease in number } \\
\text { of births, decrease in oocyte number, decrease in fertilization rate, decrease in fetal growth } \\
\text { before implantation and also increase in malondyaldehyde hormones and estrogen. }\end{array}$ & $(90)$ \\
\hline Intragastric & $\begin{array}{l}\text { This study showed that nanosized titanium dioxide reduces body weight, relative ovarian } \\
\text { weight, reduced fertility, changes in sex hormone levels, atretic follicle increases, } \\
\text { inflammation, and necrosis. }\end{array}$ & $(91)$ \\
\hline Gavage & $\begin{array}{l}\text { This study shows that } \mathrm{TiO}_{2} \mathrm{NPs} \text { can lead to premature ovarian failure (POF), decreased levels } \\
\text { of estradiol hormones, progesterone, increased levels of luteinizing hormone, follicle- } \\
\text { stimulating hormone, anti-Müllerian hormone, thyroid-stimulating hormone, free } \\
\text { tetraiodothyronine, anti-nuclear antibody and anti-thyroid peroxidase antibody levels in } \\
\text { serum. Thus, } \mathrm{TiO}_{2} \text { nanoparticles can through alterations in hormones and autoimmunity } \\
\text { markers lead to POF. }\end{array}$ & $(92)$ \\
\hline \multirow[t]{2}{*}{-} & $\begin{array}{l}\text { According to studies, the findings indicate adverse effects of Titanium dioxide nanoparticles } \\
\left(\mathrm{TiO}_{2} \text { - NPs) on sperm. These nanoparticles are able to cross the blood-testis barrier, }\right. \\
\text { inflammation, cytotoxicity, and gene expression changes. In addition, these nanoparticles may } \\
\text { cause damage to sperm DNA. }\end{array}$ & $(93)$ \\
\hline & $\begin{array}{l}\text { This study shows that } \mathrm{TiO}_{2}-\mathrm{NP} \text { has been shown to be dose-dependent toxicity. These } \\
\text { nanoparticles at higher doses can induce autophagy and necrosis in Sertoli cells, and } \\
\text { consequently negatively affected spermatogenic cells and testicular morphology becomes. }\end{array}$ & $(94)$ \\
\hline
\end{tabular}

\subsection{Nano-zinc oxide ( $\mathrm{ZnO})$}

Zinc oxide nanoparticles have a wide variety of applications in various fields. Numerous studies and evidence have shown that zinc oxide nanoparticles have adverse effects on the production system. These nanoparticles have the ability to cross barriers that protect the reproductive system. These nanoparticles have adverse effects on the female reproductive system and fertility (95-97). Table 2 shows some of the adverse effects of zinc oxide nanoparticles on the reproductive system.

\subsection{Silver nanoparticles (AgNPs)}

Silver nanoparticles (AgNPs) have been used extensively in areas such as antibiotics, textile, wound dressings, medical devices, antibacterial, antifungal, anti-cancer, and antigenic applications. But along with its diverse development and applications, there are potential risks to human health, especially for reproductive system. $(98,99)$. Table 3 shows some of these disadvantages and problems.

\subsection{Gold nanoparticles}

Gold nanoparticles have the wide variety of applications. Some researchers divide the biological applications of these nanoparticles into four main classes: labeling, delivering, heating, and sensing (100). These nanoparticles can be used in: gene delivery (101), PPTT (102), catalyzed (103), chemical sensing, biological imaging, drug delivery, and cancer treatment (104). Although the unique properties of gold nanoparticles provide a wide range of biological applications, there is evidence that these nanoparticles are toxic at high concentrations (105). Some of these adverse effects are listed in Table 4.

\subsection{Iron oxide nanoparticles}

Iron oxide NPs are used in many fields including: as contrast agents in imaging Magnetic resonance imaging (MRI), drug delivery, etc. One of the other major applications of these nanoparticles is environmental remediation applications. Thus these nanoparticles are in a greater risk of human exposures (106-115). Table 5 shows some of the risks of this nanoparticle associated with the reproductive system.

\subsection{Nickel nanoparticles (Ni NPs)}

Nickel nanoparticles (Ni NPs) are used in a variety of fields due to their unique properties. Some of these features include: catalysts, high-density magnetic. These nanoparticles can be used to treat cancer (116), catalytic (117), biosensor (118), nuclear waste, biochemical products, and cells $(119,120)$. These nanoparticles may cause problems for humans. Some studies and evidence have shown that these nanoparticles may cause apoptosis, oxidative stress, and DNA damage.

Table 2: Shows some of the entry routes and adverse effects of zinc oxide nanoparticles on the reproductive system 


Intravenously

Intraperitoneally

(IP)

Gastrointestinally

Orally

Orally

Intraperitoneal (IP)

Intravenous

Table 3: Shows some of the entry routes and adverse effects of AgNPs on the reproductive system

\begin{tabular}{|c|c|}
\hline The entrance route & Function \\
\hline Intravenous & $\begin{array}{l}\text { AgNPs may interfere with the process of meiosis progression and expression of imprinted } \\
\text { genes. Also these nanoparticles reduce the methylation of } \mathrm{Zac}_{1} \text { gene and increase the } \\
\text { methylation of } \mathrm{Igf}_{2} \mathrm{r} \text {. In fact, AgNPs can stop the process of dividing meiosis. }\end{array}$ \\
\hline Intr & $\begin{array}{l}\text { This study shows that AgNPs are transmitted through } \mathrm{Ag}^{+} \text {formation in cellsTM4cells and } \\
\text { granulosa cells, and germ cells, induce damage. These nanoparticles are also by releasing } \\
\text { cytochrome } \mathrm{c} \text { in to the cytosol induces apoptotic induction. }\end{array}$ \\
\hline
\end{tabular}

increase damage and apoptosis in fetal oocyte. Toxic effects of these nanoparticles to their

ion - shedding Their ability and low solubility are attributed. Their side depends on the dose.

(121-123)

Influence and accumulation of zinc oxide nanoparticles can reduce the number of oocytes, impaired primordial follicle assembly and folliculo genesis dynamics in the ovaries.

This study showed that oxide nanoparticles have a dose-dependent toxicity. At higher doses, these nanoparticles increase in the corpusluteum, follicular cysts, inflammatory cells infiltration and fibrosis. Histopathological changes in ovary, epithelial destruction,

hyperplasia of endometrial glands and changes in estrogen and progesterone levels (decrease in the level of these hormones in high doses and increase in low doses).

Studies have shown that the use of zinc oxide nanoparticles before and during pregnancy and

lactation may increase the risk of health to pregnant women and their fetuses.

This study shows that ZNP can induce adverse and toxic dose-dependent effects in testicular germ cells. These nanoparticles may be present in Sertolicell also has adverse effects and The multinucleated giant cell formation and sloughing of immature germ cells from the seminiferoustubules are evidence of this. In addition, these nanoparticles may have the ability to induce apoptosis or autophagy in testicular germ cells.

In this study, it was shown that zinc oxide nanoparticles through regulation of specific signaling pathways may have adverse effects on female reproductive systems.

$\mathrm{ZnO}$ nanoparticles have destructive effects on the cells of the male reproductive system.

These effects are as reduction and loss of cells in seminiferous tubules in testicular tissue. In fact, these nanoparticles are able to degenerate and decrease cell types in the seminiferous tubules (such as spermatogonia, primary spermatocyte, spermatid and sperm cells), outer part of the tubules (such as leydig, fibroblast cells and blood vesicles), seminiferous epithelium and tubule are diameters.

This study showed that these nanoparticles have dose-dependent toxicity. These nanoparticles may cause fetal death and decrease them weigh too. cell apoptosis through the production of ROS and p53-, p21-, and caspase - 3 - dependent regulatory mechanisms.
Evidence suggests that silver nanoparticles have adverse effects on testicular tissue. These adverse effects include: Histopathology revealed abnormal arrangement, deformity, atrophy, degeneration, and necrosis of epithelial cells of somniferous tubules. These nanoparticles also reduce the concentration of testosterone. Silver nanoparticles also have a negative effect on the

(140, 143number of sperm, leading to a decrease in them.

This study suggests that silver nanoparticles may have adverse effects on spermatogenesis. Silver nanoparticles also affect sperm quality.

This study showed that AgNPs lead to DNA damage in germ cells. These nanoparticles also lead to changes in the seminiferous tubule morphometry. The study also showed that by reducing the size of these nanoparticles, their toxicity increased and also showed that the dosedependent toxicity nanoparticles.

The study found that AgNPs had adverse effects. In pregnant mothers who were injected with these nanoparticles, delayed physical development and impaired cognitive behavior in offspring occurred. The nanoparticles were also found in placenta, breast milk. These nanoparticles can also accumulate in testes and visceral yolk sac.

This study shows that AgNP has adverse effects on oocyte maturation. This nanoparticle can also have negative effects on arly embryonic development. This nanoparticle is likely to trigger

$(135,140-$

Intravenous

Table 4: Shows the Routes of entry of gold nanoparticles and some of their negative effects on the reproductive system 


\begin{tabular}{|l|l|l|}
\hline- & $\begin{array}{l}\text { This study suggests that gold nanoparticles may have toxic and adverse effects on ovarian } \\
\text { granulosa cells. }\end{array}$ \\
\hline - & This study shows that gold nanoparticles can have size-dependent toxicity. \\
\hline Intraperitoneal & $\begin{array}{l}\text { Gold nanoparticles can cause changes in the levels of LH, FSH and testosterone hormones. In } \\
\text { fact, increase the amount of these hormones. It is predicted that these nanoparticles may also } \\
\text { increase infertility by increasing the levels of these hormones. }\end{array}$ \\
\hline (156) \\
\hline Intravenously & $\begin{array}{l}\text { This study shows that gold nanoparticles with smaller sizes are more widely distributed in body } \\
\text { tissues and may be distributed in some organs, including the liver, spleen, kidney, testis, thymus, } \\
\text { heart, lung, and brain. }\end{array}$ \\
\hline (157)
\end{tabular}

Table 5: shows some of the adverse effects of iron oxide nanoparticles on the reproductive system

\begin{abstract}
The entrance route
In this study, the effect of surface charge of iron oxide nanoparticles on the passage of placenta and effect on the fetus was studied. Research has shown that both are positively and negatively charged iron oxide nanoparticles have the ability to cross the placenta and accumulate in the fetal body, although nanoparticles with more positive charge accumulate and thus show more toxicity.
\end{abstract}

Intraperitoneally

Intraperitoneally

In this study, the effect of iron oxide nanoparticles coated with dimercaptosuccinic acid (DMSA) in pregnant mice was investigated. This study showed that high doses of this nanoparticle reduced spermatogonia, spermatocytes, spermatids and mature sperm. In fact, high doses of this nanoparticle impair fetal growth.

The results of this study showed that conventional iron oxide particle induced more accumulation and more oxidative stress than nanoparticles. This can negatively effect on the fertility of female rats.

Intratracheally

.

Orally
This study showed that female mice may show more sensitive response to FeNPs exposure than male mice.

This study showed that $\mathrm{NP} \mathrm{Fe}_{2} \mathrm{O}_{3}$ has the ability to cross the testicular barrier and enter it. The accumulation of these nanoparticles in the testicles causes oxidative stress and apoptosis. These nanoparticles also caused histopathological lesions such as vacuolization, detachment, and sloughing of germ cells. In addition, testosterone levels increased with exposure to these nanoparticles.

In this study, the effects of $\mathrm{Fe}_{2} \mathrm{O}_{3}$-NPs on seminal vesicle and prostate gland were studied in mice. These nanoparticles caused food consumption, water intake, and organo-somatic index in mice. These nanoparticles can cause oxidative stress. Therefore, these nanoparticles cause (162)

Table 6: Shows some of the entrance route of nickel nanoparticles and their negative effects on the reproductive system

The entrance route

Gavage

Function

This study shows that nickel nanoparticles (Ni NPs) have adverse effects on the reproductive system. These adverse effects are: Ovarian lymphocytosis, vascular dilatation 


\begin{tabular}{|c|c|c|}
\hline & $\begin{array}{l}\text { and congestion, inflammatory cell infiltration. Overall weight loss, increased epididymis- } \\
\text { to-body weight ratio, altered sperm motility, decreased FSH levels, and testosterone (T). }\end{array}$ & \\
\hline Gavage & $\begin{array}{l}\text { This study showed that NiNPs caused significant toxicity in rat tests. These nanoparticles } \\
\text { create their adverse effects by inducing oxidative stress and apoptosis. Also, this study } \\
\text { showed the dose-dependent toxicity of these nanoparticles. }\end{array}$ & (164) \\
\hline- & $\begin{array}{l}\text { In this study, the effects of nanoparticles (Ni NPs) on gamete quality of marine organisms } \\
\text { and on the consequences on fertility potential were investigated. The results showed that } \\
\text { these nanoparticles induced oxidative stress, lipid peroxidation and DNA fragmentation, } \\
\text { and altered MMP and sperm morphology. These nanoparticles also affect the ability to } \\
\text { induce and create anomalies in the offspring. }\end{array}$ & (165) \\
\hline Gavage & $\begin{array}{l}\text { In this study, the effects of Ni NPs on ovarian cells were investigated. The results showed } \\
\text { swelling mitochondrion swelling, disappearance of mitochondrial cristae, and enlargement } \\
\text { of the endoplasmic reticulum. The nanoparticles also increased some of the enzymes and } \\
\text { proteins associated with apoptosis, including mRNAs associated with caspase 3, caspase } \\
8 \text { and and caspase } 9 \text {, and the proteins Fas, Cyt c, Bax, and Bid in the ovaries. }\end{array}$ & (166) \\
\hline \multirow[t]{2}{*}{ Gavage } & $\begin{array}{l}\text { In this study, the effects of nickel nanoparticles on spermatogenesis were investigated. The } \\
\text { results showed various cell apoptosis and disordered arrangement of cells arranged in the } \\
\text { seminiferous tubules. The results also showed that these nanoparticles also increased } \\
\text { sperm motility. }\end{array}$ & (167) \\
\hline & $\begin{array}{l}\text { In this study, the effect of Ni NPs on Sertoli-germ co-cultured cells (Sertoli-germ cells) } \\
\text { was investigated. The results showed that these nanoparticles can induce apoptosis on } \\
\text { Sertoli-germ cells. }\end{array}$ & (168) \\
\hline
\end{tabular}

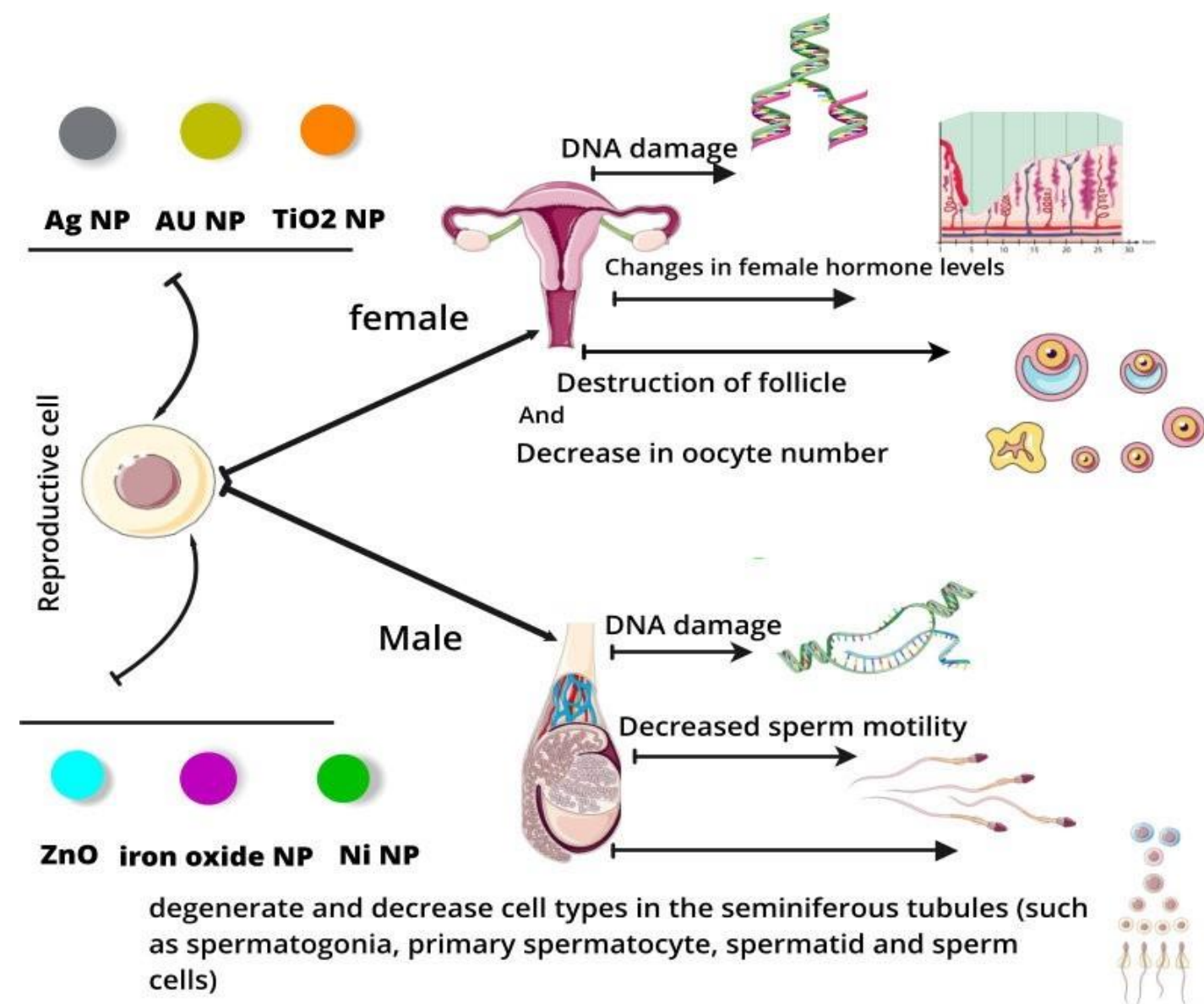

Figure 1: shows some of the adverse effects that metal nanoparticles (titanium oxide, gold, iron, silver, zinc oxide, nickel) have on the reproductive system

Another issue with this nanoparticle is the damage can cause to the reproductive system (167); That Table 6 lists some of these adverse effects. Figure 1 also shows some of the adverse effects of these nanoparticles on the reproductive system.

\section{Conclusion}

With the advent of nanotechnology in various fields of medicine and industry, a great change has taken place. A development that led to unique applications that were unlikely to occur before. Nanotechnology, like many other sciences, has a number of disadvantages, despite having many advantages. 
One of these disadvantages is the adverse effects that some nanoparticles have on the reproductive system. These adverse effects have so far appeared as adverse effects on sex hormone levels, Adverse effects on the sperm maturation cycle as well as its quality, negative effects on the process of oocyte maturation and inhibition, changes in sexual behavior, adverse effects on the fetus, and so on. All of the above evidence highlights the need for more efficient and safe use of nano particles. In such a way that they have less risk. In general, these adverse effects indicate the need to use nanomaterials with greater safety and less hazards.

\section{Reference}

1. Fathi M, Mozafari MR, Mohebbi M. Nanoencapsulation of food ingredients using lipid based delivery systems. Trends in food science \& technology. 2012;23(1):13-27.

2. Schummer J. Multidisciplinarity, interdisciplinarity, and patterns of research collaboration in nanoscience and nanotechnology. Scientometrics. 2004;59(3):425-65.

3. Singh T, Shukla S, Kumar P, Wahla V, Bajpai VK, Rather IA. Application of nanotechnology in food science: perception and overview. Frontiers in microbiology. 2017;8:1501.

4. Zhu M, Nie G, Meng H, Xia T, Nel A, Zhao Y. Physicochemical properties determine nanomaterial cellular uptake, transport, and fate. Accounts of chemical research. 2013;46(3):622-31.

5. Gao G, Ze Y, Li B, Zhao X, Zhang T, Sheng L, et al. Ovarian dysfunction and gene-expressed characteristics of female mice caused by long-term exposure to titanium dioxide nanoparticles. Journal of hazardous materials. 2012;243:19-27.

6. Singh S, Nalwa HS. Nanotechnology and health safety-toxicity and risk assessments of nanostructured materials on human health. Journal of nanoscience and nanotechnology. 2007;7(9):3048-70.

7. Misra R, Acharya S, Sahoo SK. Cancer nanotechnology: application of nanotechnology in cancer therapy. Drug discovery today. 2010;15(19-20):842-50.

8. Jain KK. Nanodiagnostics: application of nanotechnology in molecular diagnostics. Expert review of molecular diagnostics. 2003;3(2):153-61

9. Wang X, Wang Y, Chen ZG, Shin DM. Advances of cancer therapy by nanotechnology. Cancer research and treatment: official journal of Korean Cancer Association. 2009;41(1):1.

10. Duarah S, Pujari K, Durai RD, Narayanan VHB. Nanotechnologybased cosmeceuticals: a review. Int J Appl Pharm. 2016;8:8-12.

11. Kaur IP, Agrawal R. Nanotechnology: a new paradigm in cosmeceuticals. Recent patents on drug delivery \& formulation. 2007;1(2):171-82

12. Baruah S, Dutta J. Nanotechnology applications in pollution sensing and degradation in agriculture: a review. Environmental Chemistry Letters. 2009;7(3):191-204.

13. Beheshtkhoo N, Kouhbanani MAJ, Savardashtaki A, Amani AM, Taghizadeh S. Green synthesis of iron oxide nanoparticles by aqueous leaf extract of Daphne mezereum as a novel dye removing material. Appl Phys A. 2018;124(5):363.

14. Sonvico F, Dubernet C, Colombo P, Couvreur P. Metallic colloid nanotechnology, applications in diagnosis and therapeutics. Current pharmaceutical design. 2005;11(16):2091-105.

15. Joshi M, Bhattacharyya A, Ali SW. Characterization techniques for nanotechnology applications in textiles. 2008

16. Dutta S. Applications and development of nanomaterials and nanotechnology: role of chemical engineers. Recent Patents on Chemical Engineering. 2012;5(3):197-205.

17. Kouhbanani MAJ, Beheshtkhoo N, Amani AM, Taghizadeh S, Beigi V, Bazmandeh AZ, et al. Green synthesis of iron oxide nanoparticles using Artemisia vulgaris leaf extract and their application as a heterogeneous Fenton-like catalyst for the degradation of methyl orange. Materials Research Express. 2018;5(11):115013

18. Kouhbanani MAJ, Beheshtkhoo N, Taghizadeh S, Amani AM, Alimardani V. One-step green synthesis and characterization of iron oxide nanoparticles using aqueous leaf extract of Teucrium polium and their catalytic application in dye degradation.
Advances in Natural Sciences: Nanoscience and Nanotechnology. 2019;10(1):015007.

19. Lohrasbi S, Kouhbanani MAJ, Beheshtkhoo N, Ghasemi Y, Amani AM, Taghizadeh S. Green Synthesis of Iron Nanoparticles Using Plantago major Leaf Extract and Their Application as a Catalyst for the Decolorization of Azo Dye. BioNanoScience. 2019;9(2):317-22

20. Santos CS, Gabriel B, Blanchy M, Menes O, García D, Blanco M, et al. Industrial applications of nanoparticles-a prospective overview. Materials Today: Proceedings. 2015;2(1):456-65.

21. Reza Mozafari M, Johnson C, Hatziantoniou S, Demetzos C. Nanoliposomes and their applications in food nanotechnology. Journal of liposome research. 2008;18(4):309-27.

22. DeRosa MC, Monreal C, Schnitzer M, Walsh R, Sultan Y. Nanotechnology in fertilizers. Nature nanotechnology. 2010;5(2):91.

23. Iavicoli I, Leso V, Beezhold DH, Shvedova AA. Nanotechnology in agriculture: Opportunities, toxicological implications, and occupational risks. Toxicology and applied pharmacology. 2017;329:96-111.

24. Farokhzad OC, Langer R. Impact of nanotechnology on drug delivery. ACS nano. 2009;3(1):16-20.

25. Jianrong $C$, Yuqing $M$, Nongyue $H$, Xiaohua $W$, Sijiao L. Nanotechnology and biosensors. Biotechnology advances. 2004;22(7):505-18.

26. Couvreur P, Vauthier C. Nanotechnology: intelligent design to treat complex disease. Pharmaceutical research. 2006;23(7):141750.

27. Kamat PV. Photophysical, photochemical and photocatalytic aspects of metal nanoparticles. ACS Publications; 2002.

28. Kouhbanani MAJ, Beheshtkhoo N, Fotoohiardakani G, HosseiniNave H, Taghizadeh S, Amani AM. Green Synthesis and Characterization of Spherical Structure Silver Nanoparticles Using Wheatgrass Extract. Journal of Environmental Treatment Techniques. 2019;7(1):142-9.

29. Kouhbanani MAJ, Beheshtkhoo N, Nasirmoghadas $P$, Yazdanpanah S, Zomorodianc K, Taghizadeh S, et al. Green Synthesis of Spherical Silver Nanoparticles Using Ducrosia Anethifolia Aqueous Extract and Its Antibacterial Activity. Journal of Environmental Treatment Techniques. 2019;7(3):4616.

30. Kulkarni N, Muddapur U. Biosynthesis of metal nanoparticles: a review. Journal of Nanotechnology. 2014;2014.

31. Jain PK, Huang X, El-Sayed IH, El-Sayed MA. Review of some interesting surface plasmon resonance-enhanced properties of noble metal nanoparticles and their applications to biosystems. Plasmonics. 2007;2(3):107-18

32. Adiseshaiah PP, Hall JB, McNeil SE. Nanomaterial standards for efficacy and toxicity assessment. Wiley Interdisciplinary Reviews: Nanomedicine and Nanobiotechnology. 2010;2(1):99-112.

33. Carlson C, Hussain SM, Schrand AM, K. Braydich-Stolle L, Hess $\mathrm{KL}$, Jones RL, et al. Unique cellular interaction of silver nanoparticles: size-dependent generation of reactive oxygen species. The journal of physical chemistry B. 2008;112(43):13608 19.

34. Chen HH, Yu C, Ueng TH, Chen S, Chen BJ, Huang KJ, et al. Acute and subacute toxicity study of water-soluble polyalkylsulfonated $\mathrm{C} 60$ in rats. Toxicologic pathology. 1998;26(1):143-51.

35. Chen HH, Yu C, Ueng T-H, Liang C-T, Chen B-J, Hong C-C, et al. Renal effects of water-soluble polyarylsulfonated $\mathrm{C} 60$ in rats with an acute toxicity study. Fullerenes, Nanotubes, and Carbon Nanostructures. 1997;5(7):1387-96.

36. Hussain SM, Schlager JJ. Safety evaluation of silver nanoparticles: inhalation model for chronic exposure. Toxicological sciences. 2009;108(2):223-4.

37. Lam C-W, James JT, McCluskey R, Hunter RL. Pulmonary toxicity of single-wall carbon nanotubes in mice 7 and 90 days after intratracheal instillation. Toxicological sciences. 2004;77(1):126-34

38. Nel A, Xia T, Mädler L, Li N. Toxic potential of materials at the nanolevel. science. 2006;311(5761):622-7

39. Schanen BC, Karakoti AS, Seal S, Drake III DR, Warren WL, Self WT. Exposure to titanium dioxide nanomaterials provokes 
inflammation of an in vitro human immune construct. Acs Nano. 2009;3(9):2523-32.

40. Shvedova A, Castranova V, Kisin E, Schwegler-Berry D, Murray A, Gandelsman V, et al. Exposure to carbon nanotube material: assessment of nanotube cytotoxicity using human keratinocyte cells. Journal of toxicology and environmental health Part A. 2003;66(20):1909-26.

41. Araujo L, Sheppard M, Löbenberg R, Kreuter J. Uptake of PMMA nanoparticles from the gastrointestinal tract after oral administration to rats: modification of the body distribution after suspension in surfactant solutions and in oil vehicles. International journal of pharmaceutics. 1999;176(2):209-24.

42. Boudreau MD, Imam MS, Paredes AM, Bryant MS, Cunningham CK, Felton RP, et al. Differential effects of silver nanoparticles and silver ions on tissue accumulation, distribution, and toxicity in the Sprague Dawley rat following daily oral gavage administration for 13 weeks. Toxicological Sciences. 2016;150(1):131-60.

43. Braydich-Stolle LK, Lucas B, Schrand A, Murdock RC, Lee T, Schlager JJ, et al. Silver nanoparticles disrupt GDNF/Fyn kinase signaling in spermatogonial stem cells. Toxicological sciences. 2010;116(2):577-89.

44. Garcia TX, Costa GM, França LR, Hofmann M-C. Sub-acute intravenous administration of silver nanoparticles in male mice alters Leydig cell function and testosterone levels. Reproductive Toxicology. 2014;45:59-70.

45. Hussein MM, Ali HA, Saadeldin IM, Ahmed MM. Querectin alleviates zinc oxide nanoreprotoxicity in male albino rats. Journal of biochemical and molecular toxicology. 2016;30(10):489-96.

46. Kim JS, Yoon T-J, Yu KN, Kim BG, Park SJ, Kim HW, et al. Toxicity and tissue distribution of magnetic nanoparticles in mice. Toxicological Sciences. 2006;89(1):338-47.

47. Lafuente D, Garcia T, Blanco J, Sánchez D, Sirvent J, Domingo J, et al. Effects of oral exposure to silver nanoparticles on the sperm of rats. Reproductive Toxicology. 2016;60:133-9.

48. Manin O, Nikolaev V, Kolomil̆tsev A, Lebedenko I. Comparative toxicological evaluation of domestic golden alloys for soldering. Stomatologiia. 2007;86(1):64.

49. Mathias FT, Romano RM, Kizys MM, Kasamatsu T, Giannocco G, Chiamolera MI, et al. Daily exposure to silver nanoparticles during prepubertal development decreases adult sperm and reproductive parameters. Nanotoxicology. 2015;9(1):64-70.

50. Morishita Y, Yoshioka Y, Satoh H, Nojiri N, Nagano K, Abe Y, et al. Distribution and histologic effects of intravenously administered amorphous nanosilica particles in the testes of mice. Biochemical and biophysical research communications. 2012;420(2):297-301

51. Nirmal NK, Awasthi KK, John PJ. Effects of Nano-Graphene Oxide on Testis, Epididymis and Fertility of Wistar Rats. Basic \& clinical pharmacology \& toxicology. 2017;121(3):202-10.

52. Rollerova E, Jurcovicova J, Mlynarcikova A, Sadlonova I, Bilanicova D, Wsolova L, et al. Delayed adverse effects of neonatal exposure to polymeric nanoparticle poly (ethylene glycol)-block-polylactide methyl ether on hypothalamicpituitary-ovarian axis development and function in Wistar rats. Reproductive Toxicology. 2015;57:165-75.

53. Schädlich A, Hoffmann S, Mueller T, Caysa H, Rose C, Göpferich A, et al. Accumulation of nanocarriers in the ovary: A neglected toxicity risk? Journal of controlled release. 2012;160(1):105-12.

54. Shahin NN, Mohamed MM. Nano-sized titanium dioxide toxicity in rat prostate and testis: possible ameliorative effect of morin. Toxicology and applied pharmacology. 2017;334:129-41

55. Taylor U, Barchanski A, Garrels W, Klein S, Kues W, Barcikowski S, et al. Toxicity of gold nanoparticles on somatic and reproductive cells. Nano-biotechnology for biomedical and diagnostic Research: Springer; 2012. p. 125-33.

56. Casselman S, Schulte-Hostedde A. Reproductive roles predict sexual dimorphism in internal and external morphology of lake whitefish, Coregonus clupeaformis. Ecology of Freshwater Fish. 2004;13(3):217-22.

57. Heikkilä $M$, Peltoketo $H$, Vainio $S$. Wnts and the female reproductive system. Journal of Experimental Zoology. 2001;290(6):616-23.

58. TSENG L. A STUDY ON THE REPRODUCTIVE SYSTEM OF AGROTIS YPSILON ROTT.[J]. Acta Entomologica Sinica. $1982 ; 3$
59. Clark RL, Antonello JM, Grossman SJ, Wise LD, Anderson C, Bagdon WJ, et al. External genitalia abnormalities in male rats exposed in utero to finasteride, a $5 \alpha$-reductase inhibitor. Teratology. 1990;42(1):91-100

60. Crescioli C, Maggi M, Vannelli G, Ferruzzi P, Granchi S, Mancina $\mathrm{R}$, et al. Expression of functional estrogen receptors in human fetal male external genitalia. The Journal of Clinical Endocrinology \& Metabolism. 2003;88(4):1815-24.

61. Murashima A, Kishigami S, Thomson A, Yamada G. Androgens and mammalian male reproductive tract development. Biochimica et Biophysica Acta (BBA)-Gene Regulatory Mechanisms. 2015;1849(2):163-70.

62. Short RV. Sexual selection and its component parts, somatic and genital selection, as illustrated by man and the great apes. Advances in the Study of Behavior. 9: Elsevier; 1979. p. 131-58.

63. Ernsting MJ, Murakami M, Roy A, Li S-D. Factors controlling the pharmacokinetics, biodistribution and intratumoral penetration of nanoparticles. Journal of Controlled Release. 2013;172(3):782-94.

64. Trbojevich RA, Torres AM. Biological Synthesis, Pharmacokinetics, and Toxicity of Different Metal Nanoparticles. Metal Nanoparticles in Pharma: Springer; 2017. p. 451-68.

65. Dussert AS, Gooris E, Hemmerle J. Characterization of the mineral content of a physical sunscreen emulsion and its distribution onto human stratum corneum. International journal of cosmetic science. 1997;19(3):119-29.

66. Kiss B, Bíró T, Czifra G, Tóth BI, Kertész Z, Szikszai Z, et al. Investigation of micronized titanium dioxide penetration in human skin xenografts and its effect on cellular functions of human skinderived cells. Experimental dermatology. 2008;17(8):659-67.

67. Mavon A, Miquel C, Lejeune O, Payre B, Moretto P. In vitro percutaneous absorption and in vivo stratum corneum distribution of an organic and a mineral sunscreen. Skin pharmacology and physiology. 2007;20(1):10-20.

68. Nohynek GJ, Lademann J, Ribaud C, Roberts MS. Grey goo on the skin? Nanotechnology, cosmetic and sunscreen safety. Critical reviews in toxicology. 2007;37(3):251-77.

69. Sadrieh N, Wokovich AM, Gopee NV, Zheng J, Haines D, Parmiter D, et al. Lack of significant dermal penetration of titanium dioxide from sunscreen formulations containing nano-and submicron-size $\mathrm{TiO} 2$ particles. Toxicological Sciences. 2010;115(1):156-66.

70. Teichmann A, Pissavini M, Ferrero L, Dehais A, Zastrow L, Richter $\mathrm{H}$, et al. Investigation of the homogeneity of the distribution of sunscreen formulations on the human skin: characterization and comparison of two different methods. Journal of biomedical optics. 2006;11(6):064005.

71. Geraets L, Oomen AG, Krystek P, Jacobsen NR, Wallin H, Laurentie $\mathrm{M}$, et al. Tissue distribution and elimination after oral and intravenous administration of different titanium dioxide nanoparticles in rats. Particle and fibre toxicology. 2014;11(1):30.

72. Jani PU, McCarthy DE, Florence AT. Titanium dioxide (rutile) particle uptake from the rat GI tract and translocation to systemic organs after oral administration. International journal of pharmaceutics. 1994;105(2):157-68.

73. Rincker M, Hill G, Link J, Meyer A, Rowntree J. Effects of dietary zinc and iron supplementation on mineral excretion, body composition, and mineral status of nursery pigs. Journal of anima science. 2005;83(12):2762-74.

74. Vance ME, Kuiken T, Vejerano EP, McGinnis SP, Hochella Jr MF, Rejeski D, et al. Nanotechnology in the real world: Redeveloping the nanomaterial consumer products inventory. Beilstein journal of nanotechnology. 2015;6(1):1769-80.

75. Geraets L, Oomen AG, Schroeter JD, Coleman VA, Cassee FR Tissue distribution of inhaled micro-and nano-sized cerium oxide particles in rats: results from a 28-day exposure study. Toxicological sciences. 2012;127(2):463-73.

76. Mostafalou S, Mohammadi H, Ramazani A, Abdollahi M Different biokinetics of nanomedicines linking to their toxicity; an overview. Springer; 2013.

77. Hou J, Wan X, Wang F, Xu G, Liu Z, Zhang T. Effects of titanium dioxide nanoparticles on development and maturation of rat preantral follicle in vitro. Academic Journal of Second Military Medical University. 2009;30(8):869-73.

78. Ilani M, Alaee S, Khodabandeh Z, Jamhiri I, Owjfard M. Effect of titanium dioxide nanoparticles on the expression of apoptotic 
markers in mouse blastocysts. Toxicol Environ Chem. 2018;100(2):228-34.

79. Di Virgilio A, Reigosa M, Arnal P, De Mele MFL. Comparative study of the cytotoxic and genotoxic effects of titanium oxide and aluminium oxide nanoparticles in Chinese hamster ovary (CHOK1) cells. Journal of hazardous materials. 2010;177(1-3):711-8.

80. Guo L, Liu X-H, Qin D, Gao L, Zhang H, Liu J-Y, et al. Effects of nanosized titanium dioxide on the reproductive system of male mice. Zhonghua nan ke xue= National journal of andrology. 2009; 15(6):517-22.

81. Alaee S, Ilani M. Effect of titanium dioxide nanoparticles on male and female reproductive systems. Journal of Advanced Medical Sciences and Applied Technologies. 2017;3(1):3-8

82. Morgan AM, Ibrahim MA, Noshy PA. Reproductive toxicity provoked by titanium dioxide nanoparticles and the ameliorative role of Tiron in adult male rats. Biochemical and biophysical research communications. 2017;486(2):595-600.

83. Gougeon A. Regulation of ovarian follicular development in primates: facts and hypotheses. Endocrine reviews. 1996;17(2):121-55.

84. HUGHES JR FM, GOROSPE WC. Biochemical identification of apoptosis (programmed cell death) in granulosa cells: evidence for a potential mechanism underlying follicular atresia. Endocrinology. 1991;129(5):2415-22.

85. Johnson AL. Intracellular mechanisms regulating cell survival in ovarian follicles. Animal reproduction science. 2003;78(3-4):185201.

86. Perez GI, Robles R, Knudson CM, Flaws JA, Korsmeyer SJ, Tilly JL. Prolongation of ovarian lifespan into advanced chronological age by Bax-deficiency. Nature genetics. 1999;21(2):200-3.

87. Tilly JL, Kowalski KI, Johnson AL, Hsueh AJ. Involvement of apoptosis in ovarian follicular atresia and postovulatory regression. Endocrinology. 1991;129(5):2799-801.

88. Hong F, Si W, Zhao X, Wang L, Zhou Y, Chen M, et al. TiO2 nanoparticle exposure decreases spermatogenesis via biochemical dysfunctions in the testis of male mice. Journal of agricultural and food chemistry. 2015;63(31):7084-92.

89. Ali N, Amiri BA, Melika G. The effect of titanium dioxide nanoparticles injection in neonatal period on ovaries in mature rats. GSC Biological and Pharmaceutical Sciences. 2019;6(1):050-5.

90. Karimipour M, Javanmard MZ, Ahmadi A, Jafari A. Oral administration of titanium dioxide nanoparticle through ovarian tissue alterations impairs mice embryonic development. International Journal of Reproductive BioMedicine. 2018;16(6):397.

91. Zhao X, Ze Y, Gao G, Sang X, Li B, Gui S, et al. Nanosized TiO2induced reproductive system dysfunction and its mechanism in female mice. Plos one. 2013;8(4).

92. Hong F, Wang L. Nanosized titanium dioxide-induced premature ovarian failure is associated with abnormalities in serum parameters in female mice. International journal of nanomedicine. 2018;13:2543.

93. Santonastaso M, Mottola F, Colacurci N, Iovine C, Pacifico S, Cammarota $\mathrm{M}$, et al. In vitro genotoxic effects of titanium dioxide nanoparticles (n-TiO2) in human sperm cells. Molecular reproduction and development. 2019;86(10):1369-77.

94. Kotil T, Akbulut C, Yön ND. The effects of titanium dioxide nanoparticles on ultrastructure of zebrafish testis (Danio rerio). Micron. 2017;100:38-44.

95. Sun J, Zhang Q, Wang Z, Yan B. Effects of nanotoxicity on female reproductivity and fetal development in animal models. International journal of molecular sciences. 2013;14(5):9319-37.

96. Yamashita K, Yoshioka Y, Higashisaka K, Mimura K, Morishita Y, Nozaki M, et al. Silica and titanium dioxide nanoparticles cause pregnancy complications in mice. Nature nanotechnology. 2011;6(5):321-8.

97. Zhao Y, Li L, Min L-J, Zhu L-Q, Sun Q-Y, Zhang H-F, et al. Regulation of MicroRNAs, and the correlations of MicroRNAs and their targeted genes by zinc oxide nanoparticles in ovarian granulosa cells. PLoS One. 2016;11(5).

98. Han JW, Jeong J-K, Gurunathan S, Choi Y-J, Das J, Kwon D-N, et al. Male-and female-derived somatic and germ cell-specific toxicity of silver nanoparticles in mouse. Nanotoxicology. 2016;10(3):361-73.
99. Zhang X-F, Park J-h, Choi Y-J, Kang M-H, Gurunathan S, Kim JH. Silver nanoparticles cause complications in pregnant mice. International journal of nanomedicine. 2015;10:7057.

100.Sperling RA, Gil PR, Zhang F, Zanella M, Parak WJ. Biological applications of gold nanoparticles. Chemical Society Reviews. 2008;37(9):1896-908.

101. Ghosh P, Han G, De M, Kim CK, Rotello VM. Gold nanoparticles in delivery applications. Advanced drug delivery reviews. 2008;60(11):1307-15.

102.Huang X, Jain PK, El-Sayed IH, El-Sayed MA. Plasmonic photothermal therapy (PPTT) using gold nanoparticles. Lasers in medical science. 2008;23(3):217.

103. Corma A, Garcia H. Supported gold nanoparticles as catalysts for organic reactions. Chemical Society Reviews. 2008;37(9):2096126.

104.Alkilany AM, Murphy CJ. Toxicity and cellular uptake of gold nanoparticles: what we have learned so far? Journal of nanoparticle research. 2010;12(7):2313-33

105.Goodman CM, McCusker CD, Yilmaz T, Rotello VM. Toxicity of gold nanoparticles functionalized with cationic and anionic side chains. Bioconjugate chemistry. 2004;15(4):897-900.

106.Alam SR, Shah AS, Richards J, Lang NN, Barnes G, Joshi N, et al. Ultrasmall superparamagnetic particles of iron oxide in patients with acute myocardial infarction: early clinical experience. Circulation: Cardiovascular Imaging. 2012;5(5):559-65

107.Dickinson M, Scott TB. The application of zero-valent iron nanoparticles for the remediation of a uranium-contaminated waste effluent. Journal of Hazardous Materials. 2010;178(1-3):171-9.

108.Karn B, Kuiken T, Otto M. Nanotechnology and in situ remediation: a review of the benefits and potential risks. Environmental health perspectives. 2009;117(12):1813-31.

109.Li X-q, Elliott DW, Zhang W-x. Zero-valent iron nanoparticles for abatement of environmental pollutants: materials and engineering aspects. Critical reviews in solid state and materials sciences. 2006;31(4):111-22.

110.Mueller NC, Nowack B. Nanoparticles for remediation: solving big problems with little particles. Elements. 2010;6(6):395-400

111.Namdeo M, Saxena S, Tankhiwale R, Bajpai M, Mohan Y, Bajpai S. Magnetic nanoparticles for drug delivery applications. Journal of Nanoscience and Nanotechnology. 2008;8(7):3247-71.

112.Reimer P, Balzer T. Ferucarbotran (Resovist): a new clinically approved RES-specific contrast agent for contrast-enhanced MR of the liver: properties, clinical development, and applications. European radiology. 2003;13(6):1266-76

113. Valdiglesias V, Kiliç G, Costa C, Fernández-Bertólez N, Pásaro E, Teixeira JP, et al. Effects of iron oxide nanoparticles: cytotoxicity, genotoxicity, developmental toxicity, and neurotoxicity. Environmental and molecular mutagenesis. 2015;56(2):125-48.

114.Xie J, Huang J, Li X, Sun S, Chen X. Iron oxide nanoparticle platform for biomedical applications. Current medicinal chemistry. 2009;16(10):1278-94.

115.Zhang W-x. Nanoscale iron particles for environmental remediation: an overview. Journal of nanoparticle Research. 2003;5(3-4):323-32.

116.Guo D, Wu C, Li X, Jiang H, Wang X, Chen B. In vitro cellular uptake and cytotoxic effect of functionalized nickel nanoparticles on leukemia cancer cells. Journal of nanoscience and nanotechnology. 2008;8(5):2301-7.

117. Kalwar NH, Sherazi STH, Khaskheli AR, Hallam KR, Scott TB, Tagar ZA, et al. Fabrication of small 1-threonine capped nickel nanoparticles and their catalytic application. Applied Catalysis A General. 2013;453:54-9.

118. Roychoudhury A, Basu S, Jha SK. Dopamine biosensor based on surface functionalized nanostructured nickel oxide platform. Biosensors and Bioelectronics. 2016;84:72-81.

119.Bergemann C, Müller-Schulte D, Oster J, à, à Brassard L, Lübbe A. Magnetic ion-exchange nano-and microparticles for medical, biochemical and molecular biological applications. Journal of Magnetism and Magnetic Materials. 1999;194(1-3):45-52.

120.Giri S, Trewyn BG, Stellmaker MP, Lin VSY. Stimuli-responsive controlled-release delivery system based on mesoporous silica nanorods capped with magnetic nanoparticles. Angewandte Chemie International Edition. 2005;44(32):5038-44.

121.Bae YM, Park YI, Nam SH, Kim JH, Lee K, Kim HM, et al. Endocytosis, intracellular transport, and exocytosis of lanthanide- 
doped upconverting nanoparticles in single living cells. Biomaterials. 2012;33(35):9080-6

122.Moens PB, Chen DJ, Shen Z, Kolas N, Tarsounas M, Heng HH, et al. Rad51 immunocytology in rat and mouse spermatocytes and oocytes. Chromosoma. 1997;106(4):207-15

123.Zhai Q-Y, Ge W, Wang J-J, Sun X-F, Ma J-M, Liu J-C, et al. Exposure to Zinc oxide nanoparticles during pregnancy induces oocyte DNA damage and affects ovarian reserve of mouse offspring. Aging (Albany NY). 2018;10(8):2170.

124.Hosseini SM, Moshrefi AH, Amani R, Razavimehr SV, Aghajanikhah MH, Sokouti Z, et al. Subchronic effects of different doses of Zinc oxide nanoparticle on reproductive organs of female rats: An experimental study. International Journal of Reproductive BioMedicine. 2019;17(2).

125.Jo E, Seo G, Kwon J-T, Lee M, cheun Lee B, Eom I, et al. Exposure to zinc oxide nanoparticles affects reproductive development and biodistribution in offspring rats. The Journal of toxicological sciences. 2013;38(4):525-30.

126.Talebi AR, Khorsandi L, Moridian M. The effect of zinc oxide nanoparticles on mouse spermatogenesis. Journal of assisted reproduction and genetics. 2013;30(9):1203-9.

127.Zhao Y, Li L, Zhang P-F, Shen W, Liu J, Yang F-F, et al. Differential regulation of gene and protein expression by zinc oxide nanoparticles in hen's ovarian granulosa cells: specific roles of nanoparticles. PLoS One. 2015;10(10).

128.Kielbik P, Kaszewski J, Dabrowski S, Faundez R, Witkowski BS, Wachnicki L, et al. Transfer of orally administered $\mathrm{ZnO}$ : Eu nanoparticles through the blood-testis barrier: the effect on kinetic sperm parameters and apoptosis in mice testes. Nanotechnology. 2019;30(45):455101.

129.Lee J, Yu W-J, Song J, Sung C, Jeong EJ, Han J-S, et al. Developmental toxicity of intravenously injected zinc oxide nanoparticles in rats. Archives of pharmacal research. 2016;39(12):1682-92.

130.Charalambous M, Cowley M, Geoghegan F, Smith FM, Radford EJ, Marlow BP, et al. Maternally-inherited Grb10 reduces placental size and efficiency. Developmental biology. 2010;337(1):1-8.

131.Gabory A, Ripoche M-A, Le Digarcher A, Watrin F, Ziyyat A, Forné T, et al. H19 acts as a trans regulator of the imprinted gene network controlling growth in mice. Development. 2009;136(20):3413-21.

132.Gook DA, Edgar D, Borg J, Martic M. Detection of zona pellucida proteins during human folliculogenesis. Human reproduction. 2008;23(2):394-402.

133.Izquierdo-Rico M, Gimeno L, Jiménez-Cervantes C, Ballesta J, Avilés M. Biosynthesis of hamster zona pellucida is restricted to the oocyte. Theriogenology. 2011;75(3):463-72.

134.Kappil MA, Green BB, Armstrong DA, Sharp AJ, Lambertini L, Marsit CJ, et al. Placental expression profile of imprinted genes impacts birth weight. Epigenetics. 2015;10(9):842-9.

135.Kwong WY, Miller DJ, Ursell E, Wild AE, Wilkins AP, Osmond $\mathrm{C}$, et al. Imprinted gene expression in the rat embryo-fetal axis is altered in response to periconceptional maternal low protein diet. Reproduction. 2006;132(2):265-77.

136. Simon AM, Goodenough DA, Li E, Paul DL. Female infertility in mice lacking connexin 37. Nature. 1997;385(6616):525-9.

137. Tycko B, Morison IM. Physiological functions of imprinted genes. Journal of cellular physiology. 2002;192(3):245-58.

138. Varrault A, Gueydan C, Delalbre A, Bellmann A, Houssami S, Aknin C, et al. Zac1 regulates an imprinted gene network critically involved in the control of embryonic growth. Developmental cell. 2006;11(5):711-22.

139.Veitch GI, Gittens JE, Shao Q, Laird DW, Kidder GM. Selective assembly of connexin37 into heterocellular gap junctions at the oocyte/granulosa cell interface. Journal of cell science. 2004; 117(13):2699-707.

140.Johnston HJ, Hutchison G, Christensen FM, Peters S, Hankin S, Stone V. A review of the in vivo and in vitro toxicity of silver and gold particulates: particle attributes and biological mechanisms responsible for the observed toxicity. Critical reviews in toxicology. 2010;40(4):328-46.

141.Kang-Decker N, Mantchev GT, Juneja SC, McNiven MA, van Deursen JM. Lack of acrosome formation in Hrb-deficient mice. Science. 2001;294(5546):1531-3.
142.Park E-J, Bae E, Yi J, Kim Y, Choi K, Lee SH, et al. Repeateddose toxicity and inflammatory responses in mice by oral administration of silver nanoparticles. Environmental toxicology and pharmacology. 2010;30(2):162-8.

143.Boekelheide K, Fleming SL, Johnson KJ, Patel SR, Schoenfeld HA. Role of Sertoli cells in injury-associated testicular germ cell apoptosis. Proceedings of the Society for Experimental Biology and Medicine: Minireview. 2000;225(2):105-15.

144.Chen X, Schluesener HJ. Nanosilver: a nanoproduct in medical application. Toxicology letters. 2008;176(1):1-12

145.Holstein A, Eckmann C. Multinucleated spermatocytes and spermatids in human seminiferous tubules. Andrologia. 1986;18(1):5-16

146.Kim J-C, Kim K-H, Chung M-K. Testicular cytotoxicity of DA125, a new anthracycline anticancer agent, in rats. Reproductive Toxicology. 1999;13(5):391-7

147.Liu XL, Chen XY, Wang ZC, Shen T, Zhao H. Effects of exposure to bisphenol A during pregnancy and lactation on the testicular morphology and caspase-3 protein expression of ICR pups. Biomedical reports. 2013;1(3):420-4

148.Schwegler-Berry D, Goravanahally M, Nurkiewicz T, Castranova V, Sargent L. Nanotoxicologya pathologists perspective. Toxicol Pathol. 2011;39:301324.

149.Tiwari DK, Jin T, Behari J. Dose-dependent in-vivo toxicity assessment of silver nanoparticle in Wistar rats. Toxicology mechanisms and methods. 2011;21(1):13-24

150.Zhang X-F, Gurunathan S, Kim J-H. Effects of silver nanoparticles on neonatal testis development in mice. International journal of nanomedicine. 2015;10:6243.

151.Gromadzka-Ostrowska J, Dziendzikowska K, Lankoff A Dobrzyńska M, Instanes C, Brunborg G, et al. Silver nanoparticles effects on epididymal sperm in rats. Toxicology letters. 2012;214(3):251-8.

152.Ema M, Okuda H, Gamo M, Honda K. A review of reproductive and developmental toxicity of silver nanoparticles in laboratory animals. Reproductive Toxicology. 2017;67:149-64.

153.Huang CH, Yeh JM, Chan WH. Hazardous impacts of silver nanoparticles on mouse oocyte maturation and fertilization and fetal development through induction of apoptotic processes. Environmental toxicology. 2018;33(10):1039-49.

154.Stelzer R, Hutz RJ. Gold nanoparticles enter rat ovarian granulosa cells and subcellular organelles, and alter in-vitro estrogen accumulation. Journal of Reproduction and Development. 2009:0909170201-.

155.Tian X, Zhu M, Du L, Wang J, Fan Z, Liu J, et al. Intrauterine inflammation increases materno-fetal transfer of gold nanoparticles in a size-dependent manner in murine pregnancy. Small. 2013;9(14):2432-9.

156.Behnammorshedi M, Nazem H. The Effect of Gold Nanoparticle on Luteinizing Hormone, Follicle Stimulating Hormone, Testosterone and Testis In Male Rat. 2015.

157.De Jong WH, Hagens WI, Krystek P, Burger MC, Sips AJ, Geertsma RE. Particle size-dependent organ distribution of gold nanoparticles after intravenous administration. Biomaterials. 2008;29(12):1912-9.

158.Di Bona KR, Xu Y, Ramirez PA, DeLaine J, Parker C, Bao Y, et al. Surface charge and dosage dependent potential developmental toxicity and biodistribution of iron oxide nanoparticles in pregnan CD-1 mice. Reproductive Toxicology. 2014;50:36-42.

159.Poormoosavi SM, Morovvati H, Varzi HN, Behmanesh MA Shahryari A, Mohamadian B. Accumulation of iron oxide nanoparticle and conventional iron oxide in rat ovary and oxidative stress caused by it. Iranian Red Crescent Medical Journal. 2018;20(1).

160.Park E-J, Jeong U, Kim Y, Lee B-S, Cho M-H, Go Y-S Deleterious effects in reproduction and developmental immunity elicited by pulmonary iron oxide nanoparticles. Environmenta research. 2017;152:503-13

161.Sundarraj K, Manickam V, Raghunath A, Periyasamy M, Viswanathan MP, Perumal E. Repeated exposure to iron oxide nanoparticles causes testicular toxicity in mice. Environmental toxicology. 2017;32(2):594-608.

162.Sundarraj K, Raghunath A, Panneerselvam L, Perumal E. Iron oxide nanoparticles modulate heat shock proteins and organ 
specific markers expression in mice male accessory organs. Toxicology and applied pharmacology. 2017;317:12-24.

163.Kong L, Tang M, Zhang T, Wang D, Hu K, Lu W, et al. Nickel nanoparticles exposure and reproductive toxicity in healthy adult rats. International journal of molecular sciences. 2014;15(11):21253-69.

164.Kong L, Hu W, Lu C, Cheng K, Tang M. Mechanisms underlying nickel nanoparticle induced reproductive toxicity and chemoprotective effects of vitamin $\mathrm{C}$ in male rats. Chemosphere. 2019;218:259-65.

165.Gallo A, Boni R, Buttino I, Tosti E. Spermiotoxicity of nickel nanoparticles in the marine invertebrate Ciona intestinalis (ascidians). Nanotoxicology. 2016;10(8):1096-104.

166.Kong L, Gao X, Zhu J, Cheng K, Tang M. Mechanisms involved in reproductive toxicity caused by nickel nanoparticle in female rats. Environmental toxicology. 2016;31(11):1674-83.

167.Hu W, Yu Z, Gao X, Wu Y, Tang M, Kong L. Study on the damage of sperm induced by nickel nanoparticle exposure. Environmental geochemistry and health. 2019:1-10.

168. Kong L, Hu W, Gao X, Wu Y, Xue Y, Cheng K, et al. Molecular mechanisms underlying nickel nanoparticle induced rat Sertoligerm cells apoptosis. Science of The Total Environment. 2019;692:240-8. 